\title{
High-Risk Prostate Cancer: Role of Radical Prostatectomy and Radiation Therapy
}

\author{
Robert Qi Judd Moul \\ Division of Urology, Department of Surgery and Duke Cancer Institute, Duke University Medical Center, Durham, NC, USA
}

Keywords

Prostate cancer · Prostatectomy · Radiation

\section{Summary}

Up to $12 \%$ of European men aged $55-69$ years diagnosed with prostate cancer have high-risk disease and thus are at increased risk of mortality. There remains a lack of consensus on definitive treatment for prostate cancer, although both radiation therapy and radical prostatectomy are frequently utilized. Furthermore, the different types of radiation and surgical options also increase the complexity of deciding on a single treatment, as does the use of multimodal treatment plans. Here, we provide an overview of radiation therapy and radical prostatectomy in treating high-risk prostate cancer.

(C) 2015 S. Karger GmbH, Freiburg

\section{Introduction}

High-risk prostate cancer (PC) is defined by the D'Amico criteria as being bilaterally clinically palpable, extending beyond the prostatic capsule, and having serum prostate-specific antigen (PSA) levels of $\geq 20 \mathrm{ng} / \mathrm{ml}$ or a Gleason score of $\geq 8$ [1]. Up to $12 \%$ of newly diagnosed PC cases in Europe [2] and 13-29\% in the United States have been categorized as high-risk depending on whether the $\mathrm{CT} 2 \mathrm{c}$ definition was classified as high- or intermediaterisk [3]. Furthermore, there is concern that high-risk PC will see an increasing incidence as a result of the ' $\mathrm{D}$ ' rating given to PSA screening by the 2012 US Preventative Services Task Force [4]. Today, high-risk PC has a 10-year PC-specific mortality (PCSM) rate of up to about $20 \%$ [5]. However, it is currently unclear what the optimal treatment of high-risk PC is, given the lack of any randomized controlled trials (RCTs) comparing surgery and radiation. 2 popular options for treating PC are radiation therapy (RT) and radical prostatectomy (RP), both as initial therapy and as part of a multimodal treatment plan. In this article, we explore the roles of $\mathrm{RT}$ and RP in the treatment of high-risk PC.

\section{Lack of Definitive Research on Treatment}

Current research has yet to determine the best treatment for high-risk PC. No large RCT comparing RP versus RT has been completed to date, primarily due to a lack of patient accruement [6]. The ongoing Prostate testing for cancer and Treatment (ProtecT) trial is a phase III trial in 9 cities in the United Kingdom that has randomly assigned 1,643 patients to either active surveillance, RT, or RP (fig. 1) [7]. Nevertheless, this remarkable effort has provided plenty of fodder for the critics regardless of outcome, such as the low numbers of participants with Gleason $\geq 8$ on biopsy (37/1,643; $2.3 \%), \mathrm{PSA} \geq 10.0 \mathrm{ng} / \mathrm{ml}(166 / 1,643 ; 10.1 \%)$, and clinical stage T2 or higher $(394 / 1,643 ; 24.0 \%)$, as well as racial homogeneity (Caucasian 1,606/1,643; 97.7\%). Retrospective reviews directly comparing RT and RP have yet to come to a collective consensus (table 1). They also may be subject to biases in patient selection, disease and outcome classification, changes in treatment-era techniques, use of nomograms as proxy for true patient outcomes, inaccuracies in nomograms used, and more. Finally, the use of androgen deprivation therapy (ADT) or RT as adjuvant therapy may especially confound the results of studies attempting to isolate the efficacy of RP or RT in high-risk PC patients who are at increased risk of clinical and biochemical recurrence (BCR) which would ethically oblige physicians to offer further treatment.

\section{Radiation Therapy}

Men with high-risk PC are more likely to undergo RT plus ADT than to undergo RP [8]. This preference is buttressed by 2 RCTs that showed RT plus ADT to be superior to ADT alone in high-risk

\begin{tabular}{|c|c|}
\hline KARGER & $\begin{array}{l}\text { (c) } 2015 \text { S. Karger GmbH, Freiburg } \\
2296-5270 / 15 / 3812-0639 \$ 39.50 / 0\end{array}$ \\
\hline Fax +497614520714 & \\
\hline $\begin{array}{l}\text { Information@Karger.com } \\
\text { www.karger.com }\end{array}$ & $\begin{array}{l}\text { Accessible online at: } \\
\text { www.karger.com/ort }\end{array}$ \\
\hline
\end{tabular}


Fig. 1. Simplified study design for the Prostate testing for cancer and Treatment (ProtecT) phase III randomized clinical trial [7]. Patients with prostate-specific antigen (PSA) $\geq 20.0 \mathrm{ng} / \mathrm{ml}$ were ineligible for the study. All eligible patients had prostate cancer clinical stage T1c or T2.

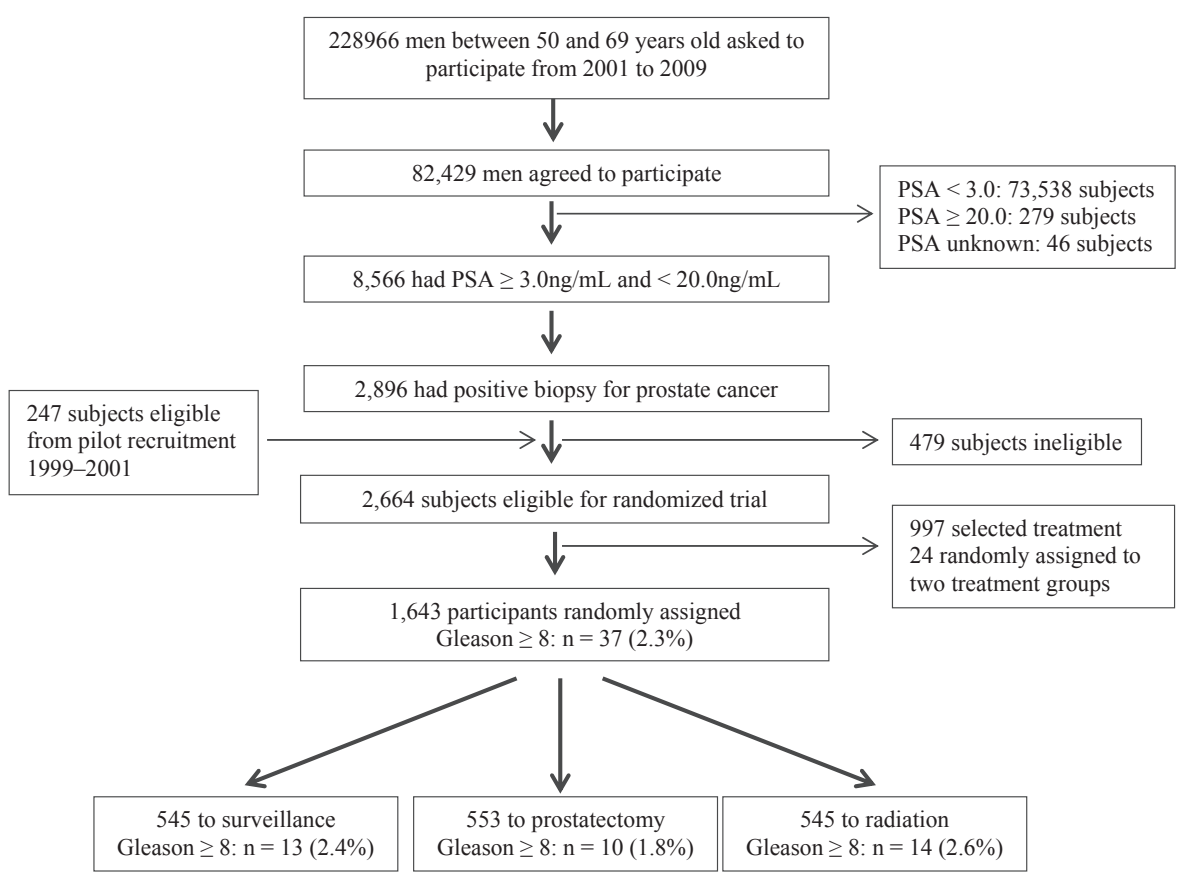

Table 1. Selected studies comparing prostate-specific mortality (PCSM) of radiation therapy (RT) with that of radical prostatectomy (RP)

\begin{tabular}{|c|c|c|c|c|c|c|}
\hline Study (year, type) [ref.] & $\begin{array}{l}\text { High-risk } \\
\text { definition }\end{array}$ & $\begin{array}{l}\text { High-risk } \\
\text { patients, } \\
\text { total, } \mathrm{n}\end{array}$ & $\begin{array}{l}\text { High-risk } \\
\text { patients per } \\
\text { treatment, } \mathrm{n}\end{array}$ & $\begin{array}{l}\text { Median } \\
\text { follow- } \\
\text { up, years }\end{array}$ & PCSM, \% & Significance \\
\hline $\begin{array}{l}\text { Narang et al. } \\
\quad(2015, \text { retrospective) [11] }\end{array}$ & $\begin{array}{l}1 \text { of following: multiple NCCN } \\
\text { high-risk features primary } \\
\text { Gleason } 5 \geq 5 \text { core biopsies of } \\
\text { Gleason } \geq 8\end{array}$ & 214 & $\begin{array}{l}\mathrm{RP}=114 \\
\mathrm{RT} / \mathrm{ADT}=100\end{array}$ & $\begin{array}{l}10 \\
10\end{array}$ & $\begin{array}{l}\mathrm{RP}=38 \\
\mathrm{RT} / \mathrm{ADT}=24\end{array}$ & no $\mathrm{p}$ value \\
\hline $\begin{array}{l}\text { Sooriakumaran et al. } \\
\text { (2014, retrospective) [21] }\end{array}$ & $\begin{array}{l}\text { cT3 N0/Nx M0/Mx and } \\
\text { Gleason } \geq 8\end{array}$ & 7,649 & $\begin{array}{l}\mathrm{RP}=2609 \\
\mathrm{RT}=5040\end{array}$ & $\begin{array}{l}5.16 \\
5.76\end{array}$ & $\begin{array}{l}\mathrm{RP}=4.5 \\
\mathrm{RT}=8.3\end{array}$ & $\mathrm{p}<0.001$ \\
\hline $\begin{array}{l}\text { Hoffman et al. } \\
\qquad \text { (2013, prospective cohort) [22] }\end{array}$ & $\begin{array}{l}\text { PSA }>10 \text { or } \\
\text { Gleason } \geq 8\end{array}$ & 437 & $\begin{array}{l}\mathrm{RP}=381 \\
\mathrm{RT}+\mathrm{ADT}=56\end{array}$ & $\begin{array}{l}15 \\
15\end{array}$ & $\begin{array}{l}\mathrm{RP}=6.6 \\
\mathrm{RT}+\mathrm{ADT}=21.4\end{array}$ & $\begin{array}{l}\mathrm{HR}=0.3695 \% \\
\text { CI } 0.20-0.64\end{array}$ \\
\hline $\begin{array}{l}\text { Westover et al. } \\
\text { (2012, retrospective) [44] }\end{array}$ & Gleason $\geq 8$ & 657 & $\begin{array}{l}\mathrm{RP}=285 \\
\mathrm{RT}+\mathrm{ADT}=372\end{array}$ & $\begin{array}{l}7.6 \\
3.6\end{array}$ & $\begin{array}{l}\mathrm{RP}=5.3 \\
\mathrm{RT}+\mathrm{ADT}=1.6\end{array}$ & $\mathrm{p}=0.16$ \\
\hline
\end{tabular}

NCCN = National Comprehensive Cancer Network; PSA = prostate-specific antigen; ADT = androgen deprivation therapy; HR = hazard ratio; $\mathrm{CI}=$ confidence interval.

PC. Widmark et al. [9] randomized 875 patients between an ADT only cohort and an RT plus ADT cohort, and showed that RT plus ADT had superior PCSM compared with ADT only (11.9 vs. $23.9 \%)$ as well as overall mortality $(29.6$ vs. $39.4 \%)$ at 10 -year follow-up. Warde et al. [10] randomized 1,205 patients between RT plus ADT and ADT only, and showed that RT plus ADT improved overall survival at 7-year follow-up compared with ADT only (74 vs. $66 \%$ ). A number of retrospective studies have shown results that favor RT over RP, with Narang et al. [11] showing lower PCSM (24 vs. $38 \%$ in a total of 214 patients) (table 1) and Stephans et al. [12] indicating lower BCR rates ( 46 vs. $53 \%$ in a total of $>1,500$ patients). Moreover, concerns about side effects, positive margins, and inadequate disease control in high-risk patients may contribute to a 'therapeutic nihilism' that sways physicians away from recommending RP and towards RT plus $\mathrm{ADT}$ for patients with high-risk PC [13].

Clinical trials have shown that higher RT dosages (78-80 Gy) have superior clinical and biochemical outcomes compared to lower RT dosages (66-70 Gy). The transition from 2D radiation to 3D-external beam radiotherapy (EBRT) in the mid-1990s and further refinement of 3D-EBRT into intensity modulated radiotherapy (IMRT) in the early 2000s were instrumental in facilitating higher RT dosages without excessive risk of side effects to the organs surrounding the prostate [14]. For high-risk PC, certain recent literature suggests that combined EBRT/IMRT and brachytherapy is superior to EBRT alone [15], IMRT alone [16], or brachytherapy alone [17], although the exact radiation dosages varied among the studies despite all being in the 'high-dosage' 
Table 2. Selected studies comparing prostate-specific mortality (PCSM) of combined radiation therapy (RT) and androgen deprivation therapy (ADT) with that of RT only

\begin{tabular}{|c|c|c|c|c|c|c|c|}
\hline $\begin{array}{l}\text { Study (year, type) } \\
\text { [ref.] }\end{array}$ & $\begin{array}{l}\text { High-risk } \\
\text { definition }\end{array}$ & $\begin{array}{l}\text { High-risk } \\
\text { patients, } \\
\text { total, } \mathrm{n}\end{array}$ & $\begin{array}{l}\text { High-risk } \\
\text { patients per } \\
\text { treatment, } \mathrm{n}\end{array}$ & $\begin{array}{l}\text { Length } \\
\text { of ADT, } \\
\text { months }\end{array}$ & $\begin{array}{l}\text { Median } \\
\text { follow-up, } \\
\text { years }\end{array}$ & PCSM, \% & Significance \\
\hline $\begin{array}{l}\text { Bolla et al. } \\
\qquad(2002, \text { RCT })[45]\end{array}$ & $\begin{array}{l}\text { cT3/T4 N0/N1 M0 } \\
\text { cT1/T2 and World Health } \\
\text { Organization grade } 3\end{array}$ & 415 & $\begin{array}{l}\mathrm{RT}+\mathrm{ADT}=207 \\
\mathrm{RT}=208\end{array}$ & 36 & 5.5 & $\begin{array}{l}\mathrm{RT}+\mathrm{ADT}=6 \\
\mathrm{RT}=21\end{array}$ & $\mathrm{p}=0.0001$ \\
\hline $\begin{array}{l}\text { Pilepich et al. } \\
\qquad(2005, \text { RCT) [46] }\end{array}$ & $\begin{array}{l}\text { cT3 } \\
\text { positive regional lymph node }\end{array}$ & 977 & $\begin{array}{l}\mathrm{RT}+\mathrm{ADT}=488 \\
\mathrm{RT}=489\end{array}$ & indefinite $^{a}$ & $\begin{array}{l}7.6 \text { (all) } \\
11 \\
\text { (survivors) }\end{array}$ & $\begin{array}{l}\mathrm{RT}+\mathrm{ADT}=16 \\
\mathrm{RT}=22\end{array}$ & $\mathrm{p}=0.0052$ \\
\hline $\begin{array}{l}\text { Granfors et al. } \\
\qquad(2006, \text { RCT }) \text { [47] }\end{array}$ & $\begin{array}{l}\text { locally advanced } \\
\text { disease stratification for } \mathrm{T} \text { and } \\
\mathrm{N} \text { stages }\end{array}$ & 91 & $\begin{array}{l}\mathrm{RT}+\mathrm{ADT}=45 \\
\mathrm{RT}=46\end{array}$ & indefinite $^{b}$ & $\begin{array}{l}9.7 \text { (all) } \\
16.5 \\
\text { (survivors) }\end{array}$ & $\begin{array}{l}\mathrm{RT}+\mathrm{ADT}=36 \\
\mathrm{RT}=57\end{array}$ & $\begin{array}{l}\mathrm{p}=0.03 \\
\text { (overall) } \\
\mathrm{p}=0.005 \\
\text { (N1 only) }\end{array}$ \\
\hline $\begin{array}{l}\text { Horwitz et al. } \\
\qquad(2008, \text { RCT })[41]\end{array}$ & $\begin{array}{l}\text { cT2c-T4, N0, } \\
\text { with PSA }<150 \mathrm{ng} / \mathrm{ml}\end{array}$ & 1,554 & $\begin{array}{l}\text { RT + short-term } \\
\text { ADT (sADT) } \\
\text { RT + long-term } \\
\text { ADT (lADT) }\end{array}$ & $\begin{array}{r}4 \\
28\end{array}$ & $\begin{array}{l}11.31 \\
11.27\end{array}$ & $\begin{array}{l}\mathrm{RT}+\mathrm{sADT}=16.1 \\
\mathrm{RT}+1 \mathrm{ADT}=11.3\end{array}$ & $\mathrm{p}=0.0042$ \\
\hline
\end{tabular}

${ }^{\mathrm{a} C}$ Continuous drug application.

bOrchiectomy.

RCT $=$ Randomized controlled trial; PSA= prostate-specific antigen .

range. In a literature review, Grim et al. [18] suggested that combined EBRT and brachytherapy had improved PSA-free progression results compared to single-modality RT in high-risk PC, although they indicated brachytherapy was superior to other RT modes in low-risk PC and combined therapy had similar outcomes to brachytherapy only in intermediate-risk PC.

\section{Radical Prostatectomy}

Many studies have suggested that RP is also a viable treatment for high-risk PC. Retrospectively reviewing patients whose lymph nodes were positive for PC, Steuber et al. [19] showed that RP plus adjuvant ADT had superior 10-year cancer-specific survival (CSS) rates compared to $\mathrm{ADT}$ alone (76 vs. $46 \%$ in a total of 158 patients), while Ghavamian et al. [20] showed that RP, pelvic lymph node dissection (PLND), and orchiectomy had superior 10-year CSS rates compared to PLND and orchiectomy (79 vs. $39 \%$ in a total of 461 patients). Evidence of lower PCSM from high-risk PC with RP than with RT have come from a retrospective study by Sooriakumaran et al. [21] (4.5 vs. $8.3 \%$ in a total of 7,649 patients) and a prospective observational study by Hoffman et al. [22] (6.6 vs. $21.4 \%$ in a total of 437 patients) (table 1). Several studies utilizing Kattan nomograms to estimate PC-specific survival curves have also concluded that patients undergoing RT have higher PCSM [23] and higher probability of metastasis [24] than patients undergoing RP, although many RP patients received salvage radiation after surgery. Proponents of RP in high-risk PC argue that RP provides more accurate pathological staging to guide disease management and prevent overtreatment with ADT, eliminates the PC 'source' to prevent cancer 'seeding' that promotes metastasis [13], and causes a rapid decrease in PSA after surgery that allows for quicker detection of persistent or recurrent PC and thus application of adjuvant therapy than other treatment modalities [25].

$\mathrm{RP}$ is typically divided into open radical retropubic prostatectomy (RRP) and robot-assisted laparoscopic prostatectomy (RALP). While RALP has become increasingly popular, there is much debate as to whether it has improved oncologic outcomes compared with traditional RRP. Both Masterson et al. [26] and Magheli et al. [27] concluded that RRP and RALP have similar $\mathrm{BCR}$ rates at 48-60 months. Positive surgical margins are an independent risk factor for $\mathrm{BCR}$, and there is no consensus on whether RALP has lower rates of positive surgical margins [28] or if the rates are similar to RRP $[29,30]$. Moreover, there have not been any RCTs comparing RRP and RALP, nor have there been any long-term follow-up studies on actual patient survival rates. Finally, there is no consensus if one type has superior functional outcomes or complication rates when surgeon experience and surgical volume are accounted for $[28,31]$.

\section{Multimodal Therapy}

Both RT and RP can be used in conjunction with each other or with other treatment modalities if one therapy is not satisfactory. Post-RP RT is frequently initiated if RP alone is deemed insufficient for cancer control, and is divided into adjuvant RT (RT provided before diagnosis of BCR from rising PSA levels) and salvage RT (RT provided after confirmation of BCR by PSA). While adjuvant RT has been shown to lower BCR, improve local control, decrease me- 
tastases, and improve overall survival compared with no post-RP treatment [32], there is a debate as to when to best provide post-RP RT. While D'Amico et al. [33] indicated that adjuvant and salvage RT had comparable all-cause mortality in pT3R0 or pT2R1 men with slow PSA doubling times, a meta-analysis of 41 studies over the past 20 years by King [34] indicated that every PSA $=0.1 \mathrm{ng} / \mathrm{ml}$ was associated with a $2.6 \%$ loss of relapse-free survival (rise in PSA $\geq 0.2 \mathrm{ng} / \mathrm{ml}$ ) after salvage RT and suggested it is desirable to initiate adjuvant RT when PSA is undetectable. Until the 3 ongoing RCTs investigating the outcomes of adjuvant versus salvage RT (RADICALS, GETUG-17, and RAVES) publish their results, post-RP salvage versus adjuvant RT will continue to be debated [35].

ADT is frequently used in conjunction with post-RP RT. Retrospective reviews indicate that combined luteinizing hormone-releasing hormone agonists plus post-RP RT have superior diseaseand PSA relapse-free status compared to post-RP RT alone [36, 37], while the initial results of the RTOG 96-01 phase III trial indicate that post-RP RT and bicalutamide also have improved PSA progression-free status compared to post-RP RT alone [38]. Ultimately, the 4 ongoing RCTs (GETUG-16, RTOG 96-01, RTOG 05-34, and RADICALS) should provide more decisive answers on the efficacy of combined post-RP RT and ADT [35].

ADT in combination with RT has been shown to be superior to RT alone as primary treatment of high-risk PC. Pollack et al. [39] reviewed that some RCTs in the 1990s comparing combined RT and ADT with only RT had shown survival benefits of combined treatment in high-risk PC. Since then, multiple RCTs have confirmed that including ADT reduces PCSM in patients initially treated with RT for high-risk PC (table 2). Current research focuses on optimizing the duration of ADT, with 2-3 years of adjunct ADT recommended as having improved outcomes over short-term adjunct ADT (<6 months) for high-risk PC [40, 41].
Finally, clinical trials have begun investigating the outcomes of combination treatment with RT, ADT, and chemotherapy as compared with standard RT and ADT. Rosenthal et al. [42] showed that $\mathrm{RT}, \mathrm{ADT}$, and combination chemotherapy with paclitaxel, estramustine, and etoposide did not improve rates of overall survival, disease-free survival, BCR, or disease progression as compared with RT and ADT only in a phase III trial. However, early data suggests that combined RT, ADT, and docetaxel and prednisone had a $4 \%$ overall survival improvement over RT and ADT only at 4-year follow-up (93 vs. 89\%) [43]. The addition of chemotherapy presents another exciting new area of research at the forefront of PC treatment.

\section{Conclusion}

A substantial proportion of PC is still initially diagnosed as high-risk PC with elevated mortality rates. However, the most appropriate treatment for high-risk PC remains unclear. Enough research that supports either RT or RP as the primary, initial treatment exists for proponents of either treatment to advocate their therapy of choice. In addition, multimodal treatments incorporating RT and RP are frequently utilized since single-modality treatment may not be sufficient for cancer control. For the foreseeable future, treatment options for high-risk PC will continue to be refined yet remain controversial.

\section{Disclosure Statement}

Mr. Qi does not report any conflicts of interest. Dr. Moul reports no conflicts of interest related to the subject matter of this article.

\section{References}

1 D'Amico AV, Whittington R, Malkowicz SB, Schultz D, Blank K, Broderick GA, Tomaszewski JE, Renshaw AA, Kaplan I, Beard CJ, Wein A: Biochemical outcome after radical prostatectomy, external beam radiation therapy, or interstitial radiation therapy for clinically localized prostate cancer. JAMA 1998;280:969-974.

2 Schröder FH, Hugosson J, Roobol MJ, Tammela TL, Ciatto S, Nelen V, Kwiatkowski M, Lujan M, Lilja H, Zappa M, Denis LJ, Recker F, Berenguer A, Määttänen L, Bangma CH, Aus G, Villers A, Rebillard X, van der Kwast T, Blijenberg BG, Moss SM, de Koning HJ, Auvinen A; ERSPC Investigators: Screening and ProstateCancer Mortality in a Randomized European Study. N Engl J Med 2009;360:1320-1328.

3 Cooperberg MR, Cowan J, Broering JM, Carroll PR: High-risk prostate cancer in the United States, 19902007. World J Urol 2008;2008:211-218.

4 Catalona WJ, D’Amico AV, Fitzgibbons WF, KosokoLasaki O, Leslie SW, Lynch HT, Moul JW, Rendell MS, Walsh PC: What the U.S. Preventive Services Task Force missed in its prostate cancer screening recommendation. Ann Intern Med 2012;157:137-138.
Cooperberg MR, Broering JM, Carroll PR: Risk assessment for prostate cancer metastasis and mortality at the time of diagnosis. J Natl Cancer Inst 2009;101: 878-887.

6 Radiation Oncology/Prostate/Localized Prostate Cancer. 2014 (cited 2015, August 7); //en.wikibooks.org/ wiki/Radiation_Oncology/Prostate/Localized_Prostate_ Cancer\#Surgery_vs_RT.

7 Lane JA, Donovan JL, Davis M, Walsh E, Dedman D, Down L, Turner EL, Mason MD, Metcalfe C, Peters TJ, Martin RM, Neal DE, Hamdy FC; ProtecT study group: Active monitoring, radical prostatectomy, or radiotherapy for localised prostate cancer: study design and diagnostic and baseline results of the ProtecT randomised phase 3 trial. Lancet Oncol 2014;15:11091118.

8 Meng MV, Elkin EP, Latini DM, Duchane J, Carroll PR: Treatment of patients with high risk localized prostate cancer: results from cancer of the prostate strategic urological research endeavor (CaPSURE). J Urol 2005;173:1557-1561.
9 Widmark A, Klepp O, Solberg A, Damber JE, Angelsen A, Fransson P, Lund JA, Tasdemir I, Hoyer M, Wiklund F, Fosså SD; Scandinavian Prostate Cancer Group Study 7; Swedish Association for Urological Oncology 3: Endocrine treatment, with or without radiotherapy, in locally advanced prostate cancer (SPCG-7/SFUO-3): an open randomised phase III trial. Lancet 2009;373:301-308.

10 Warde P, Mason M, Ding K, Kirkbride P, Brundage M, Cowan R, Gospodarowicz M, Sanders K, Kostashuk E, Swanson G, Barber J, Hiltz A, Parmar MK, Sathya J, Anderson J, Hayter C, Hetherington J, Sydes MR, Parulekar W; NCIC CTG PR.3/MRC UK PR07 investigators: Combined androgen deprivation therapy and radiation therapy for locally advanced prostate cancer: a randomised, phase 3 trial. Lancet 2011;378:2103-2111.

11 Narang A, Robertson SP, Ram AN, HE P, Sundi D, Griffith E, Singh H, DeWeese T, Honig S, McNutt TR, Ross AE, Bivalacque TJ, Shaeffer EM, Partin AW, DeWeese TL, Song D, Tran PT: Very-high-risk localized prostate cancer - outcomes following definitive radiation. Int J Radiat Oncol Biol Phys 2014;90(suppl 1): S14-S15. 
12 Stephans K, Tendulkar R, Reddy C, Stephenson A, Klein E, Kupelian P, Ciezki J. High-risk prostate cancer: radiation or surgery? Int J Radiat Oncol Biol Phys 2013;87:S371.

13 Stewart SB, Boorjian SA: Radical prostatectomy in high-risk and locally advanced prostate cancer: Mayo Clinic perspective. Urol Oncol 2015;33:235-244.

14 Thariat J, Hannoun-Levi, JM, Myint AS, Vuong T, Gerard JP: Past, present, and future of radiotherapy for the benefit of patients. Nat Rev Clin Oncol 2013;10: 52-60.

$D_{15}$ Liss AL, Abu-Isa EI, Jawad MS, Feng FY, Vance SM, Winfield RJ, Narayana V, Sandler HM, McLaughlin PW, Hamstra DA: Combination therapy improves prostate cancer survival for patients with potentially lethal prostate cancer: the impact of Gleason pattern 5 . Brachytherapy 2015; 14:502-510.

16 Wilder RB, Barme GA, Gilbert RF, Holevas RE, Kobashi LI, Reed RR, Solomon RS, Walter NL, Chittenden L, Mesa AV, Agustin JK, Lizarde J, Macedo JC, Ravera J, Tokita KM: Preliminary results in prostate cancer patients treated with high-dose-rate brachytherapy and intensity modulated radiation therapy (IMRT) vs. IMRT alone. Brachytherapy 2010;9:341-348.

17 Da Silva Franca CA, Vieira SL, Carvalho AC, Bernabé AJ, Penna AB: Localized prostate cancer with intermediate- or high-risk features treated with combined external beam radiotherapy and iodine- 125 seed brachytherapy. Brachytherapy 2010;9:307-312.

18 Grimm P, Billiet I, Bostwick D, Dicker AP, Frank S, Immerzeel J, Keyes M, Kupelian P, Lee WR, Machtens S, Mayadev J, Moran BJ, Merrick G, Millar J, Roach M, Stock R, Shinohara K, Scholz M, Weber E, Zietman A Zelefsky M, Wong J, Wentworth S, Vera R, Langley S: Comparative analysis of prostate-specific antigen free survival outcomes for patients with low, intermediate and high risk prostate cancer treatment by radical therapy. Results from the Prostate Cancer Results Study Group. BJU Int 2012;109(suppl 1):22-29.

19 Steuber T, Budäus L, Walz J, Zorn KC, Schlomm T, Chun F, Ahyai S, Fisch M, Sauter G, Huland H, Graefen M, Haese A: Radical prostatectomy improves progression-free and cancer-specific survival in men with lymph node positive prostate cancer in the prostatespecific antigen era: a confirmatory study. BJU Int 2011; 107:1755-1761.

20 Ghavamian R, Bergstralh EJ, Blute ML, Slezak J, Zincke H: Radical retropubic prostatectomy plus orchiectomy versus orchiectomy alone for $\mathrm{pTxN}+$ prostate cancer: a matched comparison. J Urol 1999;161. 1223-1227.

-21 Sooriakumaran P, Nyberg T, Akre O, Haendler L, Heus I, Olsson M, Carlsson S, Roobol MJ, Steineck G, Wiklund P: Comparative effectiveness of radical prostatectomy and radiotherapy in prostate cancer: observational study of mortality outcomes. BMJ 2014;348: g1502.

22 Hoffman RM, Koyama T, Fan KH, Albertsen PC, Barry MJ, Goodman M, Hamilton AS, Potosky AL, Stanford JL, Stroup AM, Penson DF: Mortality after radical prostatectomy or external beam radiotherapy for localized prostate cancer. J Natl Cancer Inst 2013; 105:711-718.

23 Cooperberg MR, Vickers AJ, Broering JM, Carroll PR: Comparative risk-adjusted mortality outcomes after primary surgery, radiotherapy, or androgen-deprivation therapy for localized prostate cancer. Cancer 2010; 116:5226-5234.
24 Zelefsky MJ, Eastham JA, Cronin AM, Fuks Z, Zhang Z, Yamada Y, Vickers A, Scardino PT: Metastasis after radical prostatectomy or external beam radiotherapy for patients with clinically localized prostate cancer: a comparison of clinical cohorts adjusted for case mix. J Clin Oncol 2010;28:1508-1513.

25 Maroni P: Is radical prostatectomy appropriate for very-high-risk prostate cancer patients? Yes. Oncology 2015;29:348.

26 Masterson TA, Cheng L, Boris RS, Koch MO: Open vs. robotic-assisted radical prostatectomy: a single surgeon and pathologist comparison of pathologic and oncologic outcomes. Urol Oncol 2013;31:1043-1048.

27 Magheli A, Gonzalgo ML, Su LM, Guzzo TJ, Netto G, Humphreys EB, Han M, Partin AW, Pavlovich CP: Impact of surgical technique (open vs laparoscopic vs robotic-assisted) on pathological and biochemical outcomes following radical prostatectomy: an analysis using propensity score matching. BJU Int 2011;107: 1956-1962.

28 Patel VR, Sivaraman A: Current status of robot-assisted radical prostatectomy: progress is inevitable. Oncology 2012;26:616-619.

29 Ferronha F, Barros F, Santos VV, Ravery V, Delmas V: Is there any evidence of superiority between retropubic, laparoscopic or robot-assisted radical prostatectomy? In Braz J Urol 2011;37:146-148.

30 Smith JA Jr, Herrell SD: Robotic-assisted laparoscopic prostatectomy: do minimally invasive approaches offer significant advantages? J Clin Oncol 2005;23:81708175.

31 Moul JW: Minimally invasive open retropubic prostatectomy: in experienced hands-still the gold standard. Oncology 2012;26:610-611, 615.

32 Faria EF, Chapin BF, Muller RL, Machado RD, Reis RB, Matin SF: Radical prostatectomy for locally advanced prostate cancer: current status. Urology 2015; 86:10-15.

33 D'Amico AV, Chen MH, Sun L, Lee WR, Mouraviev V, Robertson CN, Walther PJ, Polascik TJ, Albala DM, Moul JW: Adjuvant versus salvage radiation therapy for prostate cancer and the risk of death. BJU Int 2010; 106:1618-1622.

34 King CR: The timing of salvage radiotherapy after radical prostatectomy: a systematic review. Int J Radiat Oncol Biol Phys 2012;84:104-111.

35 King CR: Adjuvant versus salvage radiotherapy for high-risk prostate cancer patients. Semin Radiat Oncol 2013;23:215-221.

36 Ost P, Cozzarini C, De Meerleer G, Fiorino C, De Potter B, Briganti A, Nagler EV, Montorsi F, Fonteyne V, Di Muzio N: High-dose adjuvant radiotherapy after radical prostatectomy with or without androgen deprivation therapy. Int J Radiat Oncol Biol Phys 2012;83: 960-965.

37 King CR, Presti JC Jr, Gill H, Brooks J, Hancock SL: Radiotherapy after radical prostatectomy: does transient androgen suppression improve outcomes? Int J Radiat Oncol Biol Phys 2004;59:341-347.

38 Shipley WU, Hunt D, Lukka HR, Major P, Heney NM, Grignon D, Patel M, Bahary J, Lawton CA, Sandler HM: Initial report of RTOG 9601, a phase III trial in prostate cancer: effect of anti-androgen therapy (AAT) with bicalutamide during and after radiation therapy (RT) on freedom from progression and incidence of metastatic disease in patients following radical prostatectomy (RP) with pT2-3,N0 disease and elevated PSA levels. J Clin Oncol 2011;29(suppl 7):1.
39 Pollack A, Kuban DA, Zagars GK: Impact of androgen deprivation therapy on survival in men treated with radiation for prostate cancer. Urology 2002;60(3 suppl 1): 22-30.

40 Mohiuddin JJ, Baker BR, Chen RC: Radiotherapy for high-risk prostate cancer. Nat Rev Urol 2015;12:145154.

41 Horwitz EM, Bae K, Hanks GE, Porter A, Grignon DJ, Brereton HD, Venkatesan V, Lawton CA, Rosenthal SA, Sandler HM, Shipley WU: Ten-year follow-up of radiation therapy oncology group protocol 92-02: a phase III trial of the duration of elective androgen deprivation in locally advanced prostate cancer. J Clin Oncol 2008;26:2497-2504.

42 Rosenthal SA, Hunt D, Sartor AO, Pienta KJ, Gomella L, Grignon D, Rajan R, Kerlin KJ, Jones CU, Dobelbower M, Shipley WU, Zeitzer K, Hamstra DA, Donavanik V, Rotman M, Hartford AC, Michalski J, Seider M, Kim H, Kuban DA, Moughan J, Sandler H: A phase 3 trial of 2 years of androgen suppression and radiation therapy with or without adjuvant chemotherapy for high-risk prostate cancer: final results of Radiation Therapy Oncology Group Phase 3 Randomized Trial NRG Oncology RTOG 9902. Int J Radiat Oncol Biol Phys 2015;93:294-302.

43 Sandler HM, Hu C, Rosenthal SA, Sartor O, Gomella LG, Amin M, Purdy J, Michalski JM, Garzotto M, Pervez N, Balogh AG, Rodrigues G, Souhami L, Reaume MN, Williams SG, Hannan R, Horwitz EM, Raben A, Paulus R, Shipley WU: A phase III protocol of androgen suppression (AS) and 3DCRT/IMRT versus AS and 3DCRT/IMRT followed by chemotherapy (CT) with docetaxel and prednisone for localized, high-risk prostate cancer (RTOG 0521). J Clin Oncol 2015;33 (suppl):abstr LBA5002.

44 Westover K, Chen MH, Moul J, Robertson C, Polascik T, Dosoretz D, Katin M, Salenius S, D'Amico AV: Radical prostatectomy vs radiation therapy and androgensuppression therapy in high-risk prostate cancer. BJU Int 2012;110:1116-1121.

45 Bolla M, Collette L, Blank L, Warde P, Dubois JB, Mirimanoff RO, Storme G, Bernier J, Kuten A, Sternberg C, Mattelaer J, Lopez Torecilla J, Pfeffer JR, Lino Cutajar C, Zurlo A, Pierart M: Long-term results with immediate androgen suppression and external irradiation in patients with locally advanced prostate cancer (an EORTC study): a phase III randomised trial. Lancet 2002;360:103-106.

46 Pilepich MV, Winter K, Lawton CA, Krisch RE, Wolkov HB, Movsas B, Hug EB, Asbell SO, Grignon $\mathrm{D}$ : Androgen suppression adjuvant to definitive radiotherapy in prostate carcinoma-long-term results of phase III RTOG 85-31. Int J Radiat Oncol Biol Phys 2005;61:1285-1290.

47 Granfors T, Modig H, Damber JE, Tomic R: Longterm follow up of a randomized study of locally advanced prostate cancer treated with combined orchiectomy and external radiotherapy versus radiotherapy alone. J Urol 2006; 176:544-547. 